\title{
Horizontal Skills Mismatch in Vocational Education in Turkey: The Reasons for Out-of-Field Employment
}

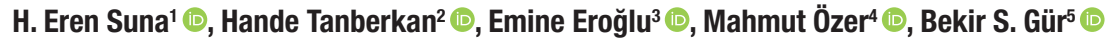

\begin{abstract}
As a type of skills mismatch, horizontal skills mismatch (HM) is a particularly important problem for vocational education and training (VET) in Turkey because the majority of VET graduates work in a different field than the one in which they were educated. This study aims to determine the reasons why some VET graduates in Turkey work in fields other than their original field of study. For this purpose, we have employed a sequential mixed-model research design, first conducting face-to-face interviews with 20 VET graduates and then applying a questionnaire to VET graduates that elicited 4,863 responses. The study uses descriptive analysis for the qualitative data from the interviews and an open-ended item from the questionnaire. The qualitative results show the most common reasons for VET graduates' employment out of their field of study to include being unable to find a job in their field of study, low wages, lack of necessary vocational skills, lack of experience, and working conditions. Quantitative results show VET graduates to want to be employed in their field of study and to make significant efforts in finding jobs that match their field. We have concluded HM to be a common problem and all the factors influencing VET graduates' out-of-field employment to be related to a weak relationship between VET and the Turkish labor market. Keywords: Skill mismatch • Vocational education and training $\bullet$ Employment $\bullet$ Labor market $\bullet$ Field of study
\end{abstract}

1 Correspondence to: H. Eren Suna, Ministry of National Education, Çankaya, Ankara Turkey. Email: herensuna@gmail.com ORCID: 0000-0002-6874-7472

2 Hande Tanberkan, Ministry of National Education, Çankaya, Ankara Turkey. Email: handetanberkan@gmail.com ORCID: 0000-0001-7142-5397

3 Emine Eroğlu, Ministry of National Education, Çankaya, Ankara Turkey. Email: emineeroglu34@gmail.com ORCID: 0000-0001-6611-3313

4 Mahmut Özer (PhD), Ministry of National Education, Çankaya, Ankara Turkey. Email: mahmutozer2002@yahoo.com ORCID: 0000-0001-8722-8670

5 Bekir S. Gür (PhD), Media and Communication Department, Faculty of Humanities and Social Sciences, Ankara Yıldırım Beyazıt University, Ankara Turkey. Email: gurbekir@gmail.com ORCID: 0000-0001-8397-5652

To cite this article: Suna, H. E., Tanberkan, H., Eroğlu, E., Özer, M., \& Gür, B. S. (2020). Horizontal skills mismatch in vocational education in Turkey: The reasons for out-of-field employment. Istanbul Üniversitesi Sosyoloji Dergisi, 40, 931-955.

https://doi.org/10.26650/SJ.2020.40.2.0101 
Education has always played an important role in countries' economic development in addition to providing students with academic and professional skills. According to human capital theory, investment in education creates positive outcomes both at the individual and national levels (Organisation for Economic Co-operation and Development [OECD], 2001). Becker (1994, p. 11) explained this phenomenon as investments in human capital (i.e., schooling, on-the-job training, medical care, immigration, etc.) lead to improved skills, knowledge, or health, and thereby raise money or psychic incomes. At the microeconomic level, investment in education increases individual production, thus enabling individuals to have a higher income. At the macroeconomic level, it increases the country's total production and the potential to develop innovative technologies, thus supporting the country's economic development (OECD, 2014; Vichet, 2018).

The real reflection of the theoretical benefits investing in education has on the economy depends on the collaboration between educational institutions and the labor market. If the skills developed through education have insufficient value in the marketplace, this disconnect leads to limited earnings on both an individual and national scale. Therefore, investment in education provides economic benefits only if a strong education-employment chain is present (Vichet, 2018).

The transition from school to work places a burden on both the education system and the labor market, and their relationship determines the smoothness of this transition. Closely linked educational programs smooth the school-to-work transition (Rözer \& Van de Werfhorst, 2020). The strength of the relationship between education and the labor market varies among countries depending on structure of their labor markets and the relationships among institutions, employers, and other stakeholders (DiPrete et al, 2017; Iannelli \& Raffe, 2007; Müller \& Gangl, 2003; Shavit \& Müller, 1998). In this context, Germany has attracted significant attention for years due to its students' smooth transitions into the workforce (Deissinger, 2015) due to its dual vocational education system having an especially strong link with its labor market (Rözer \& Van de Werfhorst, 2020). However, recent studies have demonstrated that the strength of the linkage may change within an education system (DiPrete et al., 2017; Muja et al., 2019; Rözer \& Bol, 2019; Rözer \& Van de Werfhorst, 2020), indicating the granular linkage structure of the system (DiPrete et al., 2017). For example, although Germany has stronger connections among its systems than France, some educational programs in France provide stronger linkage than the equivalent programs in Germany (Rözer \& Van de Werfhorst, 2020). Therefore, in order to accurately understand the strength of the connections between these institutions, recognizing that neither vocational nor general educational systems are homogeneous entities is important (Muja et al., 2019). 
Vocational and technical education (VET) plays a different role in the transition from school to work when compared to general education. VET is a type of education that aims to provide students with professional and vocational skills, combining theoretical courses with intensive on-the-job and internship training (OECD, 2015). In other words, VET aims to provide students with the necessary academic skills along with their vocational skills (NCVER, 2007). In a successful education system, students can gain the professional skills expected by the labor market and today's rapidly changing social and business conditions (Darling-Hammond, 2006, 2014; Goldin \& Katz, 2009). Such dynamic changes, including the widespread use of automation and artificial intelligence technologies, have caused the structure of VET to evolve (Acemoğlu \& Restrepo, 2018; Ozer, 2020d, 2020e; Ozer \& Perc, 2020; Perc et al., 2019). However, the success of a VET system is not related only to the quality of the processes and skills of VET graduates (Ozer \& Suna, 2020a). Though they may produce highly skilled graduates, VET systems are considered unproductive when those graduates cannot be employed in their field of study, when no mechanisms to reward in-field employment exist in the labor market, and when education and labor market demands are incompatible (Ozer \& Suna, 2020a).

To structure an effective VET system, the vocational and academic skills required by the labor market must first be determined prior to designing educational processes that facilitate the most effective development of these skills (OECD, 2015). Human capital educated through VET following this framework would be compatible with the needs of the labor market. Achieving this match strengthens the connection between these two institutions, thus improving VET graduates' probability of employment and integration into the labor market. With regard to skills match, national employment policies can be developed systematically based on data related to the labor market's needs. Otherwise, VET graduates' ability to take part in the labor market becomes difficult and skills mismatches in employment become widespread as a result (Bender \& Roche, 2013; Robst, 2007). This situation decreases the VET system's productivity and creates costs for both employees and employers (Somers et al., 2016).

Skills mismatch is defined as an incompatibility between the skills demanded by the labor market and those of the graduates of the educational system (European Centre for the Development of Vocational Training [CEDEFOP], 2014; International Labour Organization [ILO], 2017). Two related types of mismatches exist between graduates' skills and jobs in the labor market (ILO, 2017; Institute of Labor Economics [IZA], 2019). Vertical skills mismatch occurs when graduates are either over- or undereducated for the jobs required by the labor market (Chevalier \& Lindley, 2009; IZA, 2019). Horizontal skills mismatch occurs when the labor market is unable to find employees with the appropriate types of skills for open job positions or when employees have skills that are incompatible with their position descriptions (ILO, 2017; Nordin 
et al., 2010; Robst, 2007). Skills mismatch can also be geographical: in this case, the trained or skilled workers who could potentially fill a need in the labor market are located outside of the region where the need exists (CEDEFOP, 2020).

Skills mismatches often occur because educational institutions produce more graduates than can be employed in various vocations; thus, worker supply outpaces the job market's demand. This situation, known as skills surplus, increases competition among graduates in the labor market and forces graduates to work outside of their field of study (CEDEFOP, 2016; Ozer, 2019a). When more graduates must work outside of their field of study, their opportunities to use their skills in the labor market decrease, and the efficiency of individual and national investment in human capital resultingly decreases (Somers et al., 2016). In summary, in the case of skills surplus, the employability of graduates' decreases, thus those graduates who experience difficulty finding employment opportunities in their field of study tend to work in a field not directly related to their field of study.

Another consequence of incompatibility between the labor market and educational sector is the skills gap. Skills gaps form when the educational system does not produce enough workers with the vocational skills required by the labor market (CEDEFOP, 2016; National Centre for Vocational Education Research [NCVER], 2007). In such cases, employers may struggle to produce products and services of the same quality compared to a market where workers with the necessary skills and training are adequately supplied. For employers, providing training to individuals who do not have the skills to do the job successfully is difficult and costly. Therefore, the deterioration of the supply-and-demand balance negatively affects employment in such cases (Bartlett, 2007; Johansen \& Gatelli, 2012; Ozer \& Perc, 2020).

Studies investigating the effects of skills mismatch have identified the primary issues as graduates' being employed out of their field of study, low job satisfaction, and negative impact on graduates' well-being (Allen \& van der Velden, 2001; Büchel, 2002; Quintini, 2011; Quintano et al., 2008; Tsang, 1987). Researchers have contended that the effects of skills mismatch on the national economy are even greater in countries with high youth unemployment (Aytaş, 2014).

In summary, skills mismatch creates a significant imbalance between education and the labor market, complicates the school-to-work transition, and leads to many negative consequences for both graduates and employers. The most common type of skills mismatch in the labor market is the horizontal variety, which as a consequence has graduates working outside of their field of study. Failure to employ workers with vocational skills in positions where they can use these skills effectively is a critical issue at both the individual and national scale. While VET graduates are employed at higher rates than graduates of general education (e.g., colleges and universities), the 
main problem with VET in Turkey is that the ratio of VET graduates who are employed in their field of study is quite low (Ministry of National Education [MoNE], 2018; Ozer, 2019a). Therefore, horizontal skills mismatch in the labor market is a common problem for VET graduates in Turkey. Although studies have been conducted on the nature of the link between VET and the labor market in Turkey (Aytaş, 2014; Erikli, 2015; Hatipoğlu, 2016; Ozer \& Suna, 2020a; Susanli, 2020), little research has occurred on the reasons for VET graduates being employed in an area not directly related to their field of study (i.e., out-of-field employment).

This study investigates horizontal skills mismatch for VET graduates in Turkey, as well as their reasons for out-of-field employment. To gather opinions and reflections from this population, we have developed a questionnaire to collect information about VET graduates' employment status and emailed it to all individuals registered with the Ministry of National Education (MoNE) graduate e-portal. We also conducted face-to-face interviews with 20 VET graduates. The quantitative and qualitative data obtained from the questionnaire and interviews have been analyzed in detail to determine the respondents' reasons for out-of-field employment. This is the first comprehensive data-driven study investigating the reasons for VET graduates' outof-field employment by examining VET graduates' opinions.

\section{Horizontal Skills Mismatch and Out-of-Field Employment in Turkey}

Students in the VET system in Turkey receive education through two channels: vocational and technical Anatolian high schools (VTAH) and vocational training centers (VTC; MoNE, 2018). VTAHs constitute the types of institution where academic education is more dominant, and more than $90 \%$ of VET students in Turkey receive their education there (MoNE, 2018; Ozer \& Suna, 2019). About 10\% of VET students are trained with workplace-based apprenticeship programs at VTCs. The total number of students in both types of VET is almost two million, and these students constitute about $35 \%$ of the total number of secondary education students in Turkey (Ozer, 2018, 2019a, 2019b).

Employment numbers for VET high school graduates in Turkey are better than for general high school graduates (Ozer \& Suna, 2020a). According to the Turkish Statistical Institute (TurkStat) data, VET graduates' employment percentage is higher than for general high school graduates, and unemployment rates are lower now than they were in the past decade. Table 1 presents labor force statistics for VET graduates over the last decade compared with general high school and higher education graduates (Ozer \& Suna, 2020a).

As seen in Table 1, data from the last decade shows graduating from a VET high school to improve one's employment prospects compared to general high school graduate employment rates. VET high school graduates' unemployment rates are lower than those for higher education graduates between 2015 and 2018. 
Table 1

Labor Force Statistics for VET High School Graduates, General High School Graduates, and Higher Education Graduates (2009-2018)*

\begin{tabular}{|l|c|c|c|c|c|c|c|c|c|c|}
\hline Employment Rate (\%) & $\mathbf{2 0 0 9}$ & $\mathbf{2 0 1 0}$ & $\mathbf{2 0 1 1}$ & $\mathbf{2 0 1 2}$ & $\mathbf{2 0 1 3}$ & $\mathbf{2 0 1 4}$ & $\mathbf{2 0 1 5}$ & $\mathbf{2 0 1 6}$ & $\mathbf{2 0 1 7}$ & $\mathbf{2 0 1 8}$ \\
\hline & 42.6 & 43.3 & 45.5 & 45.8 & 46.7 & 47.1 & 47.3 & 47.2 & 47.6 & 48.0 \\
\hline General High School & 55.2 & 57.1 & 58.3 & 58.1 & 58.3 & 58.1 & 58.7 & 58.2 & 58.2 & 58.6 \\
\hline Vocational High School & 68.5 & 70.1 & 71.0 & 71.1 & 71.9 & 70.7 & 71.0 & 70.1 & 70.1 & 69.6 \\
\hline Higher Education & $\mathbf{9}$ \\
\hline
\end{tabular}

* Turkstat Employment Statistics Data (2009-2018)

However, the statistics for VET high school graduates presented in Table 1 do not provide information on whether graduates are employed in their field of study. The employment rates for VTAH graduates within and outside of their field of study are given in Figure 1 (MoNE, 2018).

As seen in Figure 1, the percentages of VTAH graduates working in their field of study ranges from $0.01 \%$ to $18.28 \%$ depending on the field, and the percentages for those working outside of their field of study range from $22.98 \%$ to $57.20 \%$. The outof-field employment rates of VET graduates are higher than the in-field employment rates across all vocational areas. Thus, a considerable skills mismatch issue comes to the fore in the labor market within the scope of VET in Turkey. The percentage of graduates working in their field of study exceeds $10 \%$ in areas such as laboratory services, aircraft maintenance, entertainment services, marketing, and retail. When examining the data, students who are graduates from VET programs are apparently largely employed outside of their fields of study. 


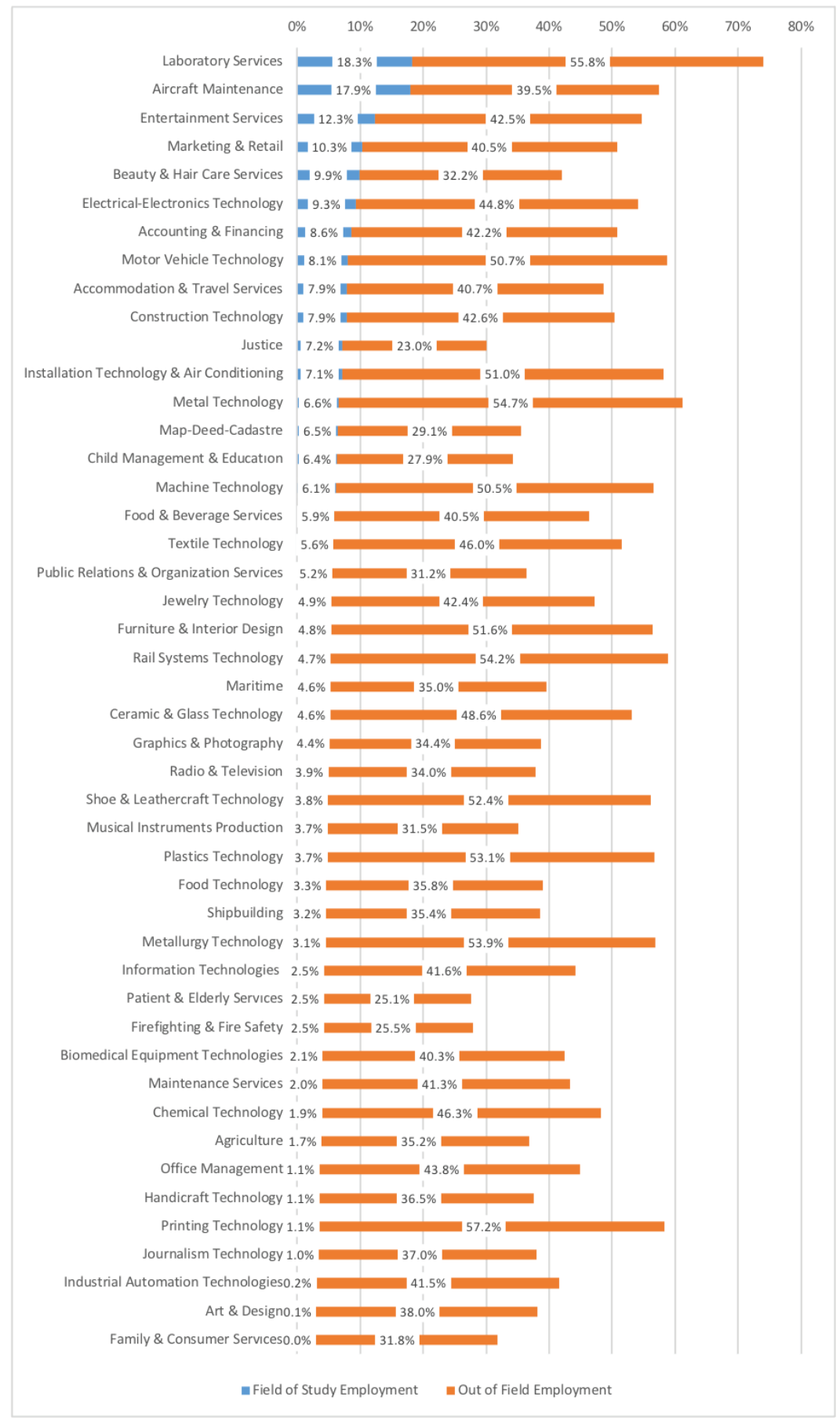

Figure 1. Employment percentages for VET high school graduates by employment status and vocational area (MoNE, 2018). 


\section{Methodology}

\section{Research Design}

This study utilizes an exploratory mixed-method design in which both quantitative and qualitative data are analyzed (Creswell \& Plano Clark, 2011). The qualitative data collection occurred during the first stage of the study, and the development of the quantitative data collection instrument (the questionnaire) is supported by the findings of the study's qualitative component (Creswell \& Creswell, 2017). Face-to-face interviews have been conducted during the data collection process primarily for the purpose of obtaining qualitative data to develop the questionnaire. An open-ended item has been added to the questionnaire to obtain secondary qualitative data from a high-volume sample. One key advantage of the exploratory design is that the inclusion of quantitative component guides are more acceptable and the findings from the qualitative component are more generalizable (Creswell \& Plano Clark, 2011). Based on the structure of the study, the data collection process began with the qualitative component followed by the quantitative component; these phases have been conducted consecutively in coherence with the exploratory sequential mixed method outlined by Creswell \& Creswell (2017). The trajectory of the exploratory design used in the present study is shown in Figure 2.

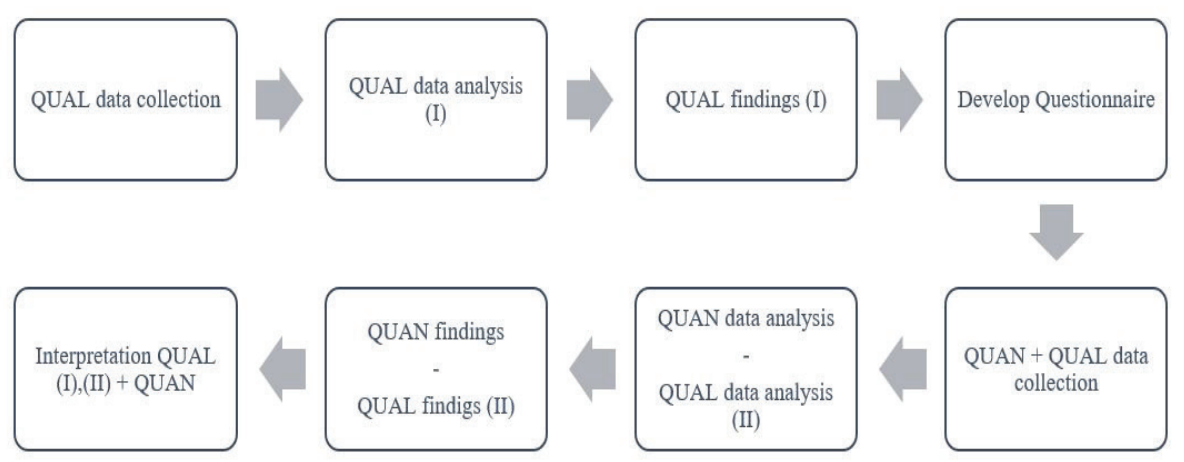

Figure 2. Exploratory sequential design used in the study (QUAL = Qualitative component; QUAN = Quantitative component).

As can be seen in Figure 2, the exploratory design requires the iterative application of qualitative and quantitative components. The findings from the qualitative component and quantitative component are analyzed separately but presented together in the Results and Discussion sections of this article.

\section{Sample}

The sample for this research consists of 4,863 graduates from Turkish VET high schools from various years. To establish contact and gather this sample, the questionnaire 
(quantitative study instrument) was emailed to 83,208 VET high school graduates registered with the MoNE e-graduate portal. The MoNE e-graduate portal is a national registry of all VET graduates in Turkey and is used to monitor their transition from VET to the labor market. The response rate for the survey was $6 \%$. Table 2 shows the distribution of the 4,863 survey respondents by demographic categories and employment characteristics.

Table 2

Distribution of the Demographic and Employment Characteristics of the Sample

\begin{tabular}{|l|c|c|c|c|c|}
\hline \multirow{4}{*}{} & & \multicolumn{2}{|c|}{ All Respondents } & \multicolumn{2}{c|}{$\begin{array}{c}\text { Respondents (Out-of-Field } \\
\text { Employment) }\end{array}$} \\
\hline \multirow{3}{*}{ Gender } & Group & $\boldsymbol{f}$ & $\mathbf{\%}$ & $\boldsymbol{f}$ & \% \\
\hline \multirow{4}{*}{ Education Level } & Female & 2,613 & 53.7 & 708 & 48.5 \\
\cline { 2 - 6 } & Male & 2,250 & 46.3 & 751 & 51.5 \\
\cline { 2 - 6 } & Two-Year (Associate) Degree & 1,985 & 40.8 & 556 & 38.1 \\
\cline { 2 - 6 } & Bachelor's Degree & 1,234 & 25.4 & 318 & 21.8 \\
\hline \multirow{4}{*}{$\begin{array}{l}\text { High School } \\
\text { Graduation Year }\end{array}$} & Graduate Degree & 99 & 2.0 & 33 & 2.3 \\
\cline { 2 - 6 } & No Info & 54 & 1.1 & 18 & 1.2 \\
\cline { 2 - 6 } & 2004 and Before & 126 & 2.6 & 33 & 2.3 \\
\cline { 2 - 6 } & $2005-2009$ & 131 & 2.7 & 40 & 2.7 \\
\hline \multirow{3}{*}{$\begin{array}{l}\text { Match Between } \\
\text { Education and Job }\end{array}$} & 2010-2014 & 1,286 & 26.4 & 382 & 26.2 \\
\cline { 2 - 6 } & 2015-2019 & 3,266 & 67.2 & 986 & 67.6 \\
\cline { 2 - 6 } & Partially matched & 751 & 15.4 & & \\
\hline
\end{tabular}

As seen in Table 2, VET high school graduates in the sample show a balanced distribution in terms of gender. Of the respondents, $93.6 \%$ had graduated from VET high schools over the last 10 years; $68.23 \%$ have continued their education after high school and completed an associate's degree or attend higher education. However, only $31.42 \%$ of the graduates answered being currently employed in a job that is fully compatible with their field of study, while $53.14 \%$ stated being employed in a job that is completely incompatible with their field of study.

In line with the aim of the study, 1,459 out of the 2,584 respondents not employed in their field of study reported being currently employed and responded to the openended item regarding their reasons for having out-of-field employment. As seen in Table 2, the distribution of gender and education level for these 1,459 respondents is similar to distribution across the entire sample.

\section{Data Collection Tools}

The VET graduates' opinions regarding employment status have been collected through a questionnaire and semi-structured face-to-face interviews. The semistructured interviews have been conducted with a certain predefined process in terms 
of theory and method, but otherwise had no strict structure (Blandford, 2013). In such interviews, researchers can interact with respondents in a detailed enough manner to enable subjective feedback while still maintaining a core methodology consistent across all respondents (Evans, 2017; Flick, 2009). Accordingly, we prepared questions about the status and reasons for VET graduates' employment within or outside of their field of study. Based on their responses to these initial questions, participants were asked additional follow-up questions to generate more in-depth answers.

These interviews were conducted with 20 VET graduates during the first phase of the study to gather qualitative data to help develop the quantitative questionnaire. We analyzed the qualitative data from the interviews to discover the themes regarding VET graduates' employment. Because little theoretical literature exists on the reasons for employment within/outside of graduates' field of study, we used both the feedback from the interviewees and the literature on skills mismatch to shape the question design. Thus, we asked the interviewees about the factors affecting their employment status after graduation and which questions they believed should be asked of survey respondents for the purposes of the study. After transcribing and analyzing the interview data, we converted the questions suggested by the interviewees into questionnaire items. The draft questionnaire was then presented to seven interviewees to solicit their feedback. After revising the draft questionnaire based on the comments from the respondents and two psychometricians, the questionnaire items were examined over a small group of VET graduates and finalized after additional revisions. The final version of the questionnaire was studied in detail by two psychometricians who concluded the instrument to have an adequate level of face validity. In line with the feedback received from the participants, we developed a short questionnaire with a limited number of options to increase the response rate. Participation in the study was voluntary, with all participants providing informed consent after reading about the study objectives and receiving assurance that their anonymity would be protected.

\section{Data Analysis}

The study has collected the quantitative data through the questionnaire items and the qualitative data through face-to-face interviews and an open-ended item on the questionnaire. The qualitative data obtained from the interviews and responses to the open-ended item on the questionnaire have been analyzed in accordance with descriptive analytical methods. Descriptive analyses of qualitative data aim to describe the considered phenomenon in a detail without any intervention (Elliott et al., 1994; Nassaji, 2015). The descriptive analysis of the qualitative data was performed independently prior to checking for consistency among individual analyses and making the respective revisions. In line with the suggestions by Creswell \& Creswell (2017) to increase analytical validity and reliability, the findings were shared with seven 
interview participants to solicit their feedback on the researchers' interpretations. Participants mostly agreed with the coding and themes, and their limited disagreements were considered and incorporated into revisions. We used the program Atlas.ti for coding and developing themes and generating a conceptual diagram to represent these findings (see Figure 3).

The questionnaire items focus on VET graduates' employment status, their reasons for being employed outside of their field of study, and their levels of satisfaction with respect to their vocational field. Given that the items on the questionnaire nominally and ordinally measure these phenomena, we have chosen not to perform parametric tests (Cooper \& Johnson, 2016). Moreover, as the items are multidimensional, each item has been examined individually. Therefore, the questionnaire items are analyzed descriptively, and the findings are presented with frequency distributions.

\section{Results}

The findings are presented in two parts. First, we provide the analysis of the qualitative data gleaned from the interviews and questionnaire. Second, we present the analysis of the quantitative data obtained from the questionnaire.

\section{Qualitative Findings}

This section gives findings from the face-to-face interviews conducted with 20 VET graduates, as well as findings from the 1,086 responses to the open-ended survey question regarding graduates' reasons for out-of-field employment. First, we present a conceptual diagram illustrating the results from the semi-structured interviews. Second, we combine the qualitative findings from the semi-structured interviews with the open-ended items from the questionnaire. Figure 3 presents the themes and sample coding from the semi-structured interviews. 


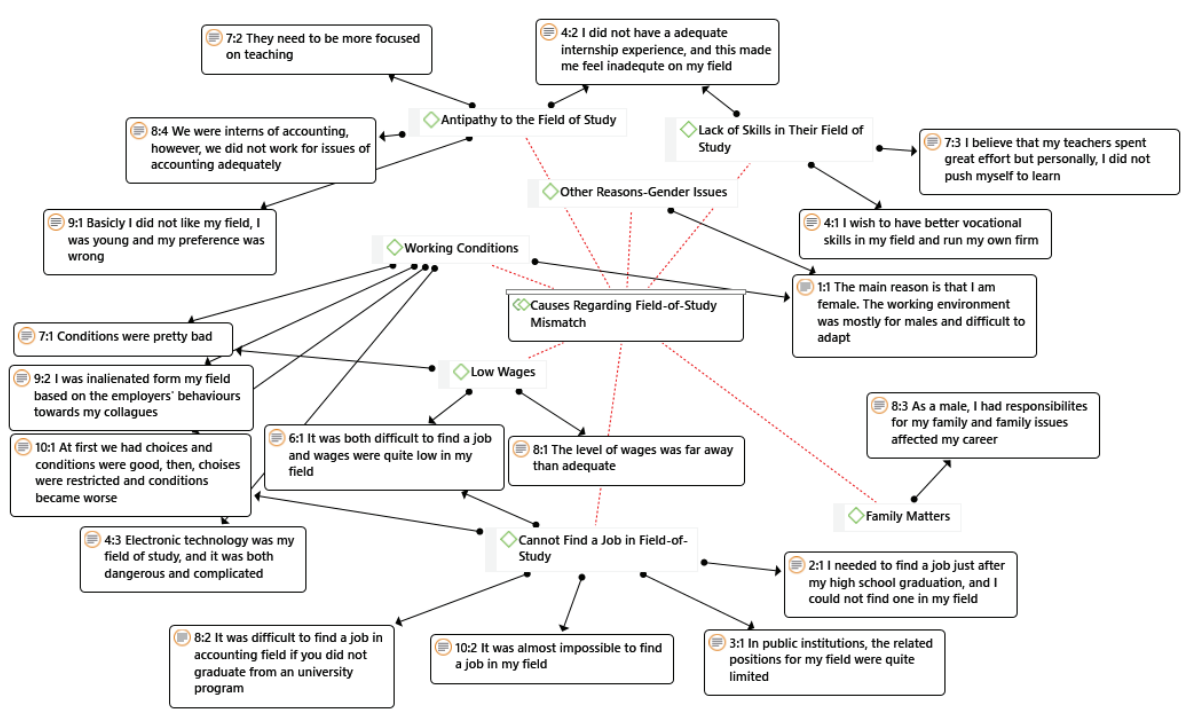

Figure 3. Conceptual diagram of the findings from the semi-structured interviews.

The themes influencing graduates' work outside of their field of study that emerged include low wages, lack of vocational skills in their field of study, working conditions, and antipathy to their field of study. The same seven themes are also importantly noted to have emerged in the responses to the open-ended item from the questionnaire (see Figure 4). We identified two additional themes from the questionnaire as well: pursuing higher education and lack of experience.

Figure 4 presents the distribution of the qualitative findings from the open-ended item in the questionnaire regarding the reasons for out-of-field employment.

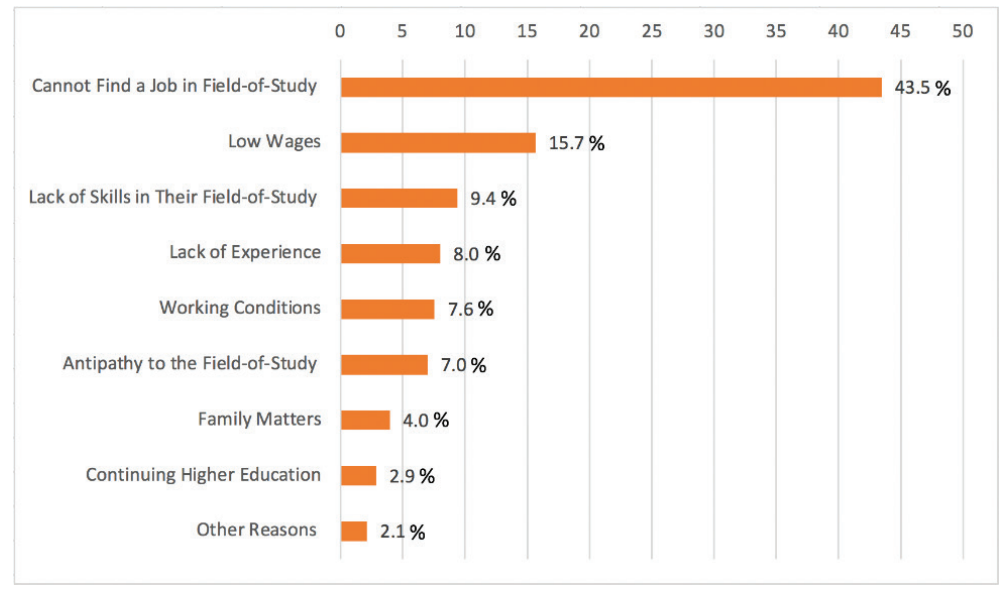

Figure 4. Distribution of participants' reasons for out-of-field employment from the questionnaire. 
As seen in Figure 4, the most common reason for out-of-field employment expressed by the VET graduates is the inability to find a job in their field of study. Other prominent reasons included low wages, lack of vocational skills in their field of study, lack of required experience, working conditions, and antipathy to the field of study. In the following sections, we expand upon these themes from the semi-structured interviews and open-ended questionnaire item.

\section{Cannot Find a Job in Field of Study}

The most frequent reason for out-of-field employment is that VET graduates were unable to find employment opportunities in their field of study. Graduates explained this with responses such as, "It is impossible to be employed in my field," "There is almost no job opportunities in the private sector in my field," "The high number of graduates [looking for employment]," and "The jobs I can find in my field are limited." Specifically, graduates working in production stated, "There are no factories related to my field;" and "There is no job opportunity in my field, and when I rarely find one, it comes with a sub-par salary." Graduates also expressed, "There is no job opportunities in public institutions in my field," "Many people are employed, even though they are not from this field," and "It is difficult to find a job because my field has too many graduates." Additional responses demonstrate open positions to be located outside of the regions where respondents live; for example, "There is no job for my field where I live" and "I could not find a job suitable for my field."

\section{Low Wages}

Answers indicating low wages include, "I had insufficient financial income in my field," "My income was insufficient," "I needed money urgently," "I worked in the field where I found a job that made sustaining my life easier," "I knew I could not make [enough] money in my field of study," and "I had to manage myself financially." Graduates also expressed this sentiment by responding, "The private sector doesn't even provide a minimum salary;" "Even if I were to work in the private sector, earning a decent wage in this field would be impossible," and "The private sector is already very problematic in my field."

\section{Lack of Skills in Their Field of Study}

Graduates who lacked the necessary vocational skills required by the job market explained their situation as follows: "The only function of school is giving a diploma," "I had to study in a different field because education was inadequate," "I couldn't fully learn the profession," "I don't feel confident about my vocational skills," "School was indifferent and inadequate," "We did not take cultural courses [i.e., teaching generic skills]," and "Our educators were insufficient." Foregrounding the need for additional 
training beyond vocational high school, some graduates explained this phenomenon saying, "High school graduates are not considered sufficient in business life, they [employers] want university graduates and this makes you feel inadequate" and "I felt inadequate because they [employers] didn't hire high school graduates."

\section{Lack of Experience}

Graduates who were unable to find work in their field of study due to lack of experience explained their experiences stating, "Employers want work experience in jobs related to my field," "Employers do not recruit new graduates in my field," "I do not have any experience because employers do not recruit high school graduates," and "Employers are looking for experienced university graduates."

\section{Working Conditions}

Participants described the working conditions in their field of study to involve "long and irregular working hours," "working conditions we do not deserve," "late working hours," "weekly off-time is not specific," "the working environment is a stressful heavy construction site," "there is no environment for a woman to work," "lack of a shift system," and "despite hard work and workload, we did not have proper salaries or tier payments." Additional reasons provided by graduates that fell under this umbrella include "because we are employed without insurance," "because employers also want cleaning duties on top of our routine tasks," "because employers don't have work ethics and regular workplaces," and "because they are part-time jobs despite full-time demand." Other responses that fell within this scope include "We work in very dangerous jobs," and "We are employed in the private sector under very extreme conditions."

\section{Antipathy to the Field of Study}

Graduates expressed negative feelings about their field of study, saying "It was too early for me to choose a field," "I do not like my field of study," "I was unhappy in the field I had chosen," "I realized that I don't like my field and I find it absurd for someone to choose their profession at the age of 13," "I hated my job because of internships," and "We were employed in irrelevant jobs in internships, thus I don't like my field."

\section{Family Matters}

Some participants identified their families' expectations as having caused their outof-field employment, explaining, "I maintain the family business," "It's my father's profession," and "It was our family company." Additional participants explained wanting to be close to their family having caused them to seek out-of-field employment, explaining 
"I could not leave my family," "I do not want to be far away from my family," and "I do not want to leave my family alone." Another common theme within this scope involves family health problems, indicated by responses like "because we have a family health problem," and "my brother is ill and I am looking after him, I cannot move away from home, so it is impossible to work regularly in a job in my field."

\section{Continuing Higher Education}

VET graduates electing to continue their education instead of working in their field of study explained their choice as follows: "They [employers] absolutely want a university degree in the workplace," "Otherwise, I do not think that I will progress further in my field of study," "I want to have a better career," "I want to work in a better field," "I do not want to be considered as a high school graduate," and "Mostly because I want to be on the brain team in the field that I want."

\section{Other Reasons}

Graduates mentioned personal situations at a lower frequency than the aforementioned themes, and these are gathered under the heading of Other Reasons. Some graduates stated employers discriminating against gender in their respective fields, stating, "They [employers] are looking more for female candidates," "They [employers] separate women from men in kitchens," "It was a problem for me to be a woman in this field," and "They [employers] requested employees be male." Moreover, some graduates explained being unable to work in their field of study because they cannot speak a foreign language. One respondent described this situation, saying, "I could not speak the required foreign language in my field." Finally, some graduates cited personal health problems as the main reason for not working in their field of study. In this regard, expressions such as "I am not working because my profession affects my physical and mental health," "I have been hyper-myopic," and "to avoid problems such as a herniated disc at a later age" were provided as reasons for out-of-field employment.

\section{Quantitative Findings}

Figure 5 illustrates the frequency distributions of the responses provided to the questionnaire. 


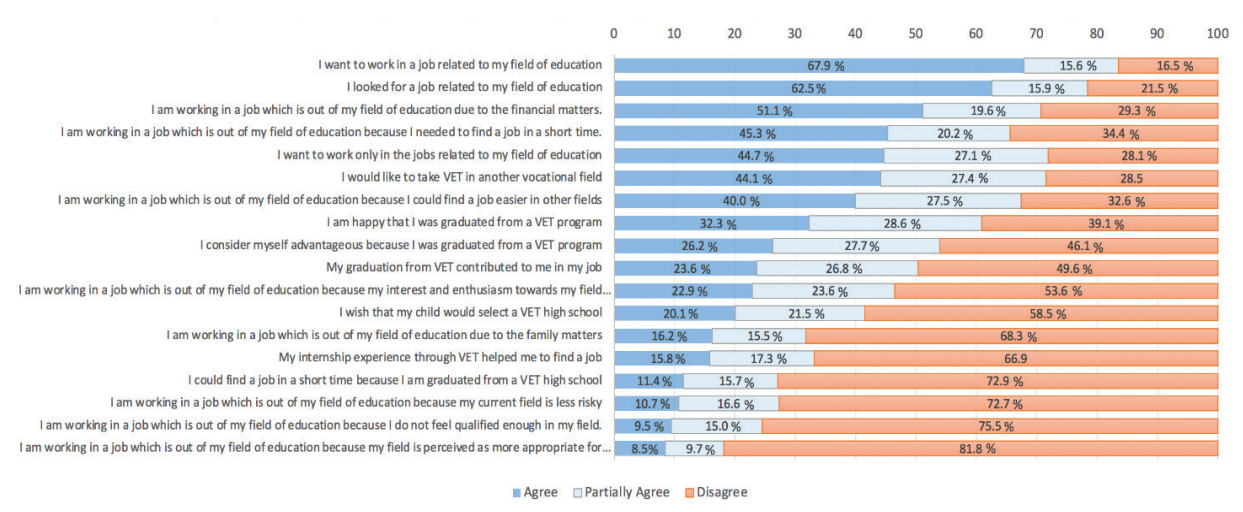

Figure 5. Frequency distributions for graduates' responses to the questionnaire items.

As seen in Figure 5, 78.45\% of the respondents stated looking for a job in their field of study. Similarly, $83.55 \%$ agreed partially or completely with the statement "I want to work in a job related to my field of study," while $71.86 \%$ desired only to work in jobs in their field of study. The high positive responses given to these three items in Figure 5 indicate that respondents largely want to work in their field of study and make significant efforts in this regard. However, only $49.63 \%$ of respondents stated being a VET graduate to have contributed (either completely or partially) to them getting their job. This finding shows that, although the VET graduates want to work in their field of study and make efforts to this end, only half of them can use their vocational skills in their job to any extent.

Of the respondents, $60.91 \%$ fully or partially agreed to being satisfied with their VET training, while $53.91 \%$ saw themselves as having an advantage due to their VET experiences. Despite this, only $27.11 \%$ of respondents stated VET to have helped them find a job in a short time.

\section{Discussions and Conclusion}

While sociologists of education have long debated whether vocational education provides "an effective safety net" to students or diverts them from "prestigious occupations," the role of vocational education in the stratification process varies across countries (Shavit \& Müller, 2000, p. 438). Accordingly, any study on the dream and realities of vocational education should be evaluated from a comparative perspective (Ozer \& Perc, 2020). Whatever the role of vocational education in strafitication, a VET system's performance is determined by the strength of the relationship between education and employment. When this relationship is not strongly established, skills mismatches arise in the labor market. Skills mismatch is not only a problem of education 
but also an important indicator of the performance of the relationship between education and the labor market. Many studies have demonstrated the tremendous consequences skills mismatches have for the labor market and for national economies (Büchel, 2002; Korber, 2019; Nordin et al., 2010; Schweri et al., 2019).

As previously stated, Germany has received praise for its smooth transition for VET graduates due to both its dual system and the size of the relevant vocational sectors (Dissinger, 2015; Rözer \& Van de Werfhorst, 2020). However, some studies maintain the strong linkages the VET approach has to result in a trade-off where stronger linkages provide an observable advantage only for younger graduates' transition while perhaps having a detrimental effect as these graduates' get older (Hanushek et al., 2011 \& 2017). However, some recent studies have shown this trade-off to not be supported (Muja et al., 2019; Rözer \& Van de Werfhorst, 2020). The contradictory findings on this issue require additional research to understand and clarify the underlying mechanism of the linkage between education and the labor market. The present study has considered the widespread problem of horizontal skills mismatch for VET graduates in Turkey and provided new evidence in its support.

VET in Turkey has contributed significantly to the country's development for years. Moreover, in times of crisis such as the COVID-19 pandemic, VET's contribution to the needs of society through its production and capacity for adaptation has become even more crucial (Ozer, 2020a, 2020b, 2020c; Ozer \& Suna, 2020b). In Turkey, VET has provided significant employment advantages for vocational school graduates. However, it also suffers from a large proportion of out-of-field employment that has led to a skills mismatch in the labor market. The reasons behind this influx of out-of-field employment have been speculated about for years, but VET graduates getting employed outside of their field of study has typically been directly attributed to the performance and quality of the VET system. Thus, this has typically been considered an educational problem. Consequently, MoNE has conducted several recent projects to improve the quality of VET in Turkey (Ozer, 2018, 2019a, 2019b; Ozer \& Suna, 2020a). However, no such effort has been made to understand the underlying reasons for the skills mismatch with regard to the labor market's responsibility. The relationship between education and employment is two-dimensional, and these concerns are shared by both educational institutions and the labor market. To our knowledge, no empirical study has occurred on the background of VET graduates' out-of-field employment in Turkey (Ozer, 2019a; Ozer \& Suna, 2020a). Therefore, we investigated the reasons for VET graduates' outof-field employment in this study. Within this framework, we have carried out a mixedmethods study to determine VET graduates' reasons for out-of-field employment.

The quantitative findings of the study show VET graduates to want to work in their field of study and to make considerable efforts in this regard. However, only a small 
number of graduates find a chance to work within their field of study. Moreover, only half of the graduates stated being able to use the skills they had gained through VET in their job. This indicates an important productivity problem both at the individual and national level. This also leads to a dissatisfaction at the personal level and loss of skilled human resources at the national level.

Qualitative findings of the study also illustrated that, among graduates' stated reasons for out-of-field employment, the most common reason is that they cannot find a job within their field of study. This finding indicates that there are not enough employment opportunities in VET graduates' vocational fields. These findings also indicate the number of graduates educated through VET to be greater than the labor market's demand in Turkey. Therefore, this study provides the first evidence of the shift of graduates to employment outside of their field of study to not be merely a problem related to educational quality but to also be a consequence of the limited employment capacity of the labor market. The high number of graduates and lack of adequate recruitment in the job market verifies the excessive worker supply in regard to Vocational and Technical Anatolian High Schools (see also Ozer \& Suna 2020a; Schweri et al., 2019). The narrower employment capacity of the labor market seems to lower the chance of graduates finding a job related to their field of study. Therefore, in order to decrease the skills mismatches present in the labor market, Turkish vocational programs must take into consideration the balance between supply and demand.

Low wages are another important reason for out-of-field employment, indicating that VET graduates' fields-of-study do not offer wages at a sufficient level. The mechanisms to encourage VET graduates to work in their field of study seem not to be adequately set up in the labor market. This also constitutes a second noticeable weakness in the relationship between VET and the labor market. In countries with a strong linkage between these institutions, the labor market provides some kind of award mechanism to encourage VET graduates to work in their field of study (De Lange et al., 2014; Korber, 2019). For example, VET graduates in Germany receive wage advantages only if they work in the field of their vocational education, otherwise their wages decrease at a rate of 10-20\% (Bol et al., 2019). However, wages in Turkey are not sufficiently distinguished because no such mechanism exists in the labor market; thus, graduates prefer to work in fields where it is easier to find work with better working conditions as opposed to seeking a job in their area of expertise (Ozer \& Suna, 2020a). Among the quantitative findings, the fact that more than half the graduates responded positively to the statement "It is easier to find a job in other fields" also confirms this phenomenon. Therefore, this finding also provides evidence that the influx of out-of-field employment does not stem from the quality of VET education but to rather be related to the lack of award/penalty mechanisms within the labor market. 
Working conditions and gender-based discrimination are also factors directly related to the labor market in Turkey. The lack of appropriate and reasonable working conditions and the use of gender as a criterion in selecting human resources encourage VET graduates' out-of-field employment. The statements from participants also indicate that employers use such criteria in hiring employees.

VET graduates' lack of experience also constitutes a serious problem when attempting to find a job within the appropriate field of study. VET graduates with little or no experience look for other out-of-field opportunities. Additionally, the distance between a graduate's home and workplace influences out-of-field employment. In this context, graduates stated being unable to find a job matching their field of study in the regions where they live. Such geographical mismatch is also a type of horizontal skills mismatch (CEDEFOP, 2020) and also indicates an infrastructure problem as many VET institutions are not located around companies that require graduates with their corresponding specialized field of study. Therefore, both companies' locations and their future needs should be considered when reorganizing VET programs. This reorganization will both improve the quality of education and decrease the probability of geographical mismatch. In fact, MoNE has already prepared a vocational skills map identifying the relevant sector and field clusters for all provinces in Turkey and has started to realign vocational programs and school locations with the related sectors (Canbal et al., 2020).

Respondents related out-of-field employment with their lack of the skills required in their field of study and antipathy to their field of study. These respondents seem to be unhappy about choosing their field of study at an early age. This is a consequence of the VET structure because it admits students directly after middle school. Respondents' unhappiness could also be related to the lack of guidance and orientation services about VET in both middle and secondary schools. Studies show that, when students are placed in schools based on their academic performance, achievement gaps between school types increase (Karaağaç Cingöz \& Gür, 2020; Suna et al., 2020a, Suna et al., 2020c). Clustering comparatively low-performing students in a particular school type such as VTAHs leads to higher levels of absenteeism and even school dropout (Bölükbaş \& Gür, 2020; Ozer et al., 2020; Suna et al., 2020a; Suna et al., 2020b). Some VET graduates also attribute their out-of-field employment to low quality education at VET schools, even though the problem only becomes visible in the labor market.

We conclude that restructuring vocational and technical education is necessary to alleviate the detrimental effects of choosing school type and field of study an early age. Moreover, increasing guidance services and improving the quality of education provided at VET schools should be top priorities. When evaluating the qualitative and quantitative findings as a whole, the causes of out-of-field employment are clearly related to failures in establishing a strong connection between the labor market and 
VET schools. To reduce VET graduates' being employed out of field, this study proposes increasing the collaboration between VET schools and industry sectors as well as establishing a supply-demand balance based rationally on the best available data regarding the vocational and general skills required in the job market. We also suggest establishing award mechanisms to provide incentives for employability in jobs related to graduates' fields-of-study.

\section{Peer-review: Externally peer-reviewed.}

Conflict of Interest: The authors declare no potential conflicts of interest with respect to the research, authorship, and/or publication of this article.

Grant Support: The authors received no financial support for the research, authorship, and/or publication of this article.

\section{References}

Acemoğlu, D., \& Restrepo, P. (2018). Artificial intelligence, automation and work. NBER Working Paper 24196. National Bureau of Economic Research, Cambridge, MA.

Allen, J., \& van der Velden, R. (2001). Educational mismatches versus skill mismatches: Effects on wages, job satisfaction, and on-the-job search. Oxford Economic Papers, 3, 434-452.

Aytaş, S. (2014). Avrupa Birliği ve Türkiye'de beceri uyuşmazlı̆̆ı. (Master's thesis). Çalışma ve Sosyal Güvenlik Bakanlığı, Ankara, Turkey.

Bartlett, W. (2007). Economic restructuring, job creation and the changing demand for skills in the Western Balkans. In A. Fetsi (Ed), Labour markets in the Western Balkans: Challenges for the future (pp. 19-50). Office for Official Publications of the European Communities.

Becker, G. S. (1994). Human capital: A theoretical and empirical analysis, with special reference to education (3rd ed.). University of Chicago Press.

Bender, K., \& Roche, K. (2013). Educational mismatch and self-employment. Economics of Education Review, 34, 85-95.

Bol, T., Eller, C. C., Van de Werfhorst, H. G., \& DiPrete, T. A. (2019). School-to-work linkages, educational mismatches, and labor market outcomes. American Sociological Review, 84(2), 275-307.

Bölükbaş, S., \& Gür, B. S. (2020). Tracking and inequality: The results from Turkey. International Journal of Educational Development, 78. https://doi.org/10.1016/j.ijedudev.2020.102262

Büchel, F. (2002). The effects of overeducation on productivity in Germany - the firms' viewpoint. Economics of Education Review, 21(3), 263-275.

Canbal, M. S., Kerkez, B., Suna, H. E., Numanoglu, K. V., \& Ozer, M. (2020). A new step for paradigm shift in the vocational and technical secondary education in Turkey: The revisions of education programs. Journal of Education and Humanities: Theory and Practice, 11(21), 1-25.

Chevalier, A., \& Lindley, J. (2009). Overeducation and the skills of UK graduates. Journal of the Royal Statistical Society: Series A (Statistics in Society), 172(2), 307-337.

Cooper, I. D., \& Johnson, T. P. (2016). How to use survey results. J Med Libr Assoc., 104(2), $174-177$.

Creswell, J. W., \& Creswell, J. D. (2017). Research design: Qualitative, quantitative, and mixed methods approaches. Sage Publications. 
Creswell, J. W., \& Plano Clark, V. L. (2011). Designing and conducting mixed methods research (2nd ed.). Sage Publications Ltd.

Darling-Hammond, L. (2006). Securing the right to learn: Policy and practice for powerful teaching and learning. Educational Researcher, 35(7), 13-24.

Darling-Hammond, L. (2014). What can PISA tell us about U.S. education policy? New England Journal of Public Policy, 26(1), 1-14.

De Lange, M., Gesthuizen, M., \& Wolbers, M. H. (2014). Youth labour market integration across Europe: The impact of cyclical, structural, and institutional characteristics. European Societies, 16(2), 194-212.

Deissinger, T. (2015). The German dual vocational education and training system as 'good practice'? Local Economy, 30(5), 557-567.

DiPrete, T. A., Eller, C. C., Bol, T., \& Van de Werfhorst, H. G. (2017). School-to-work linkages in the United States, Germany, and France. American Journal of Sociology, 122(6), 1869-1938.

Elliott, R., Shapiro, D. A., Firth-Cozens, J., Stiles, W. B., Hardy, G., Llewelyn, S. P., \& Margison, F. (1994). Comprehensive process analysis of insight events in cognitive-behavioral and psychodynamic-interpersonal therapies. Journal of Counseling Psychology, 41, 449-463.

Erikli, S. (2015). The basic problem of the labor market in Sinop: Skills mismatch. Labour World, $2,18-33$.

European Centre for the Development of Vocational Training (CEDEFOP). (2014). Skill mismatch: More than meets the eye. CEDEFOP Briefing Note. CEDEFOP.

European Centre for the Development of Vocational Training. (2016). Skill shortage and surplus occupations in Europe: CEDEFOP insights into which occupations are in high demand - and why. CEDEFOP briefing note. CEDEFOP.

European Centre for the Development of Vocational Training. (2020). Skills panorama. CEDEFOP.

Evans, C. (2017). Analysing semi-structured interviews using thematic analysis: Exploring voluntary civic participation among adults. SAGE Research Methods Datasets Part 1.

Goldin, C., \& Katz, L. (2009). The race between education and technology. Harvard University Press.

Hanushek, E. A., Schwerdt, G., Woessman, L., \& Zhang, L. (2017). General education, vocational education, and labor-market outcomes over the life-cycle. The Journal of Human Resources, $52(1), 48-87$.

Hanushek, E. A., Woessman, L., \& Zhang, L. (2011). General education, vocational education, and labor-market outcomes over the life-cycle. NBER Working Paper 17504. National Bureau of Economic Research.

Hatipoğlu, L. (2016). Avrupa Birliği’nde beceri uyumsuzluğu olgusuna yaklaşım perspektifinde Türkiye İş Kurumu için öneriler (Master's thesis). Çalışma ve Sosyal Güvenlik Bakanlığı, Ankara, Turkey.

Iannelli, C., \& Raffe, D. (2007). Vocational upper-secondary education and the transition from school. European Sociological Review, 23(1), 49-63.

International Labour Organization. (2017). How useful is the concept of skills mismatch? International Labour Organization Publishing.

IZA Institute of Labor Economics. (2019). The impact of horizontal job-education mismatches on the earnings of recent university graduates in Russia. IZA Discussion Paper No 12407. IZA Publishing. 
Johansen, J., \& Gatelli, D. (2012). Measuring mismatch in ETF partner countries: A methodological note. ETF Publishing.

Karaağaç Cingöz, Z., \& Gür, B. S. (2020). Ekonomik, sosyal ve kültürel statünün akademik başarıya etkisi: PISA 2015 ve TEOG 2017 sonuçlarının karşılaştırması. Insan \& Toplum, 10(4), 247-288. https://doi.org/10.12658/M0563

Korber, M. (2019). Does vocational education give a labour market advantage over the whole career? A comparison of the United Kingdom and Switzerland. Social Inclusion, 7(3), 202-223.

Ministry of National Education. (2018). Türkiye'de mesleki ve teknik eğitimin görünümü. Eğitim analiz ve değerlendirme serisi No: 1 . MoNE.

Muja, A., Blommaert, L., Gesthuizen, M., \& Wolbers, M. H. J. (2019). The vocational impact of educational programs on youth labor market. Research in Social Stratification and Mobility, 64, 100437.

Müller, W., \& Gangl, M. (Eds.). (2003). Transitions from education to work in Europe: The integration of youth into EU labour markets. Oxford University Press.

Nassaji, H. (2015). Qualitative and descriptive research: Data type versus data analysis. Language Teaching Research, 19(2), 129-132.

National Centre for Vocational Educational Research. (2007). What is a skill shortage? NCVER Publishing.

Nordin, M., Persson, I., \& Rooth, D. O. (2010). Education-occupation mismatch: Is there an income penalty? Economics of Education Review, 29(6), 1047-1059.

Organisation for Economic Co-operation and Development (2001). The well-being of nations: The role of human and social capital. OECD Publishing.

Organisation for Economic Co-operation and Development . (2014). Education at a glance 2014: OECD indicators. OECD Publishing.

Organisation for Economic Co-operation and Development . (2015). OECD reviews of vocational education and training: Key messages and country summaries. OECD Publishing.

Ozer, M. (2018). The 2023 Education Vision and new goals in vocational and technical education. Journal of Higher Education and Science, 8(3), 425-435.

Ozer, M. (2019a). Reconsidering the fundamental problems of vocational education and training in Turkey and proposed solutions for restructuring. Istanbul Üniversitesi Sosyoloji Dergisi, 39(2), $1-19$.

Ozer, M. (2019b). Backgrounds of problems in vocational education and training and its road map to solution in Turkey's Education Vision 2023. Journal of Higher Education and Science, 9(1), $1-11$.

Ozer, M. (2020a). Vocational education and training as "A Friend in Need" during coronavirus pandemic in Turkey. Bartın University Journal of Faculty of Education, 9(2), 1-7.

Ozer, M. (2020b). The contribution of the strengthened capacity of vocational education and training system in Turkey to the fight against COVID-19. Journal of Higher Education, 10(2), 134-140.

Ozer, M. (2020c). Educational policy actions by the Ministry of National Education in the times of COVID-19 pandemic in Turkey. Kastamonu Education Journal, 28(3), 1124-1129.

Ozer, M. (2020d). The paradigm shift in vocational education and training in Turkey. Gazi Eğitim Fakültesi Dergisi, 40(2), 357-384. 
Ozer, M. (2020e). Mesleki eğitimde paradigma değişimi: Türkiye'nin mesleki eğitim ile imtihanı. Maltepe Üniversitesi Yayınları.

Ozer, M., Gençoğlu, C., \& Suna, H. E. (2020). Policies for alleviating educational inequalities in Turkey. Ondokuz Mayıs Üniversitesi Eğitim Fakültesi Dergisi, 39(2), 294-312.

Ozer, M., \& Perc, M. (2020). Dreams and realities of school tracking and vocational education. Palgrave Communications, 6, 34. https://doi.org/10.1057/s41599-020-0409-4

Ozer, M., \& Suna, H. E. (2019) Future of vocational and technical education in Turkey and solid steps taken after Education Vision 2023. Journal of Education and Humanities: Theory and Practice, 10(20), 166-192.

Ozer, M., \& Suna, H. E. (2020a). The linkage between vocational education and labor market in Turkey: Employability and skill mismatch. Kastamonu Education Journal, 28(2), 558-569.

Ozer, M., \& Suna, H. E. (2020b). Covid-19 pandemic and education. In M. Şeker, A. Özer, \& C. Korkut (Eds.), Reflections on the pandemic: In the future of the world (pp. 157-178). TÜBA.

Perc, M., Ozer, M., \& Hojnik, J. (2019). Social and juristic challenges of artificial intelligence. Palgrave Communications, 5, 61. https://doi.org/10.1057/s41599-019-0278-x

Quintano, C., Castellano, R., \& D'Agostino, A. (2008). Graduates in economics and educational mismatch: The case study of the University of Naples 'Parthenope'1. Journal of Education and Work, 21(3), 249-271.

Quintini, G. (2011). Over-qualified or under-skilled: A review of existing literature. OECD Social, Employment and Migration Working Papers No. 121. OECD Publishing.

Robst, J. (2007). Education and job match: The relatedness of college major and work. Economics of Education Review, 26(4), 397-407.

Rözer, J., \& Bol, T. (2019). Labour market effects of general and vocational education over the lifecycle and across time: Accounting for age, period, and cohort effects. European Sociological Review, 35(5), 701-717.

Rözer, J., \& Van de Werfhorst, H. (2020). Three worlds of vocational education: Specialized and general craftsmanship in France, Germany, and The Netherlands. European Sociological Review, 36(5), 780-797. https://doi.org/10.1093/esr/jcaa025

Schweri, J., Eymann, A., \& Aepli, M. (2019). Horizontal mismatch and vocational education. Working Paper 160. University of Zurich.

Shavit, Y., \& Müller, W. (Eds.) (1998). From school to work: A comparative study of educational qualifications and occupational destinations. Clarendon Press.

Shavit, Y., \& Müller, W. (2000). Vocational secondary education, tracking, and social stratification. In M. T. Hallinan (Ed.), Handbook of the sociology of education (pp. 437-452). Springer US. https://doi.org/10.1007/0-387-36424-2_20

Somers, M. A., Cabus, S. J., Groot, W., \& van den Brink, H. M. (2016). Horizontal mismatch between employment and the field of education: Evidence from a systematic literature review. TIER Working Paper Series No 16/02. Maastricht: Top Institute for Evidence Based Education Research.

Suna, H. E., Gür, B. S., Gelbal, S., \& Ozer, M. (2020c). Fen lisesi öğrencilerinin sosyoekonomik arkaplanı ve yükseköğretime geçişteki tercihleri. Yükseköğretim Dergisi. Advance Online Publication. https://doi.org/10.2399/yod.20.734921

Suna, H. E., Tanberkan, H., Gur, B. S., Perc, M., \& Ozer, M. (2020a). Socioeconomic status and school type as predictors of academic achievement. Journal of Economy Culture and Society, 61, 41-64. 
Suna, H. E., Tanberkan, H., \& Ozer, M. (2020b). Changes in literacy of students in Turkey by years and school types: performance of students in PISA applications. Journal of Measurement and Evaluation in Education and Psychology, 11(1), 76-97.

Susanli, Z. B. (2020). Skill shortages in Turkey: Evidence firm-level data. Business and Economics Research Journal, 11(1), 95-106.

Tsang, M. (1987). The impact of underutilization of education on productivity: A case study of the US Bell companies. Economics of Education Review, 6(3), 239-254.

Vichet, S. (2018) Impacts of educational mismatches in developing countries with a focus on Cambodia. (Doctoral Thesis) Université Grenoble Alpes. 


\section{Appendix}

\section{Survey Form}

Dear participant,

This study aims to determine the vocational fields where vocational and technical education graduates are frequently employed, their opinions about the benefits of the vocational education in their profession, and the reasons why employees are employed out of their field of study. Participation is voluntary and completing the form will take about 10-15 minutes. Please answer all questions with your direct opinions. You can enlarge the spaces reserved for your answers under the questions, make your responses as long as you would like. Privacy and anonymity of your responses within the scope of the study will be protected.

Thank you for your participation.

1. Gender:

$\square$ Female $\square$ Male

2. Level of Education:

$\square$ High School Degree $\square$ Associate Degree $\square$ Undergraduate Degree $\square$ Graduate Degree

3. Year of VET Graduation:

4. From which vocational field did you graduate?

5. Were you ever employed after your graduation from VET high school?

$\square$ Yes $\square$ No

6. How long after you graduated were you employed? (Months or Years)

7. Is your current/recent job related to your vocational field?

$\square$ Strongly related $\square$ Partially related $\square$ Not related 
